\title{
Developing media literacy skills of future specialists in the contemporary teacher training education
}

\author{
Yulia Semenova ${ }^{1}$, and Svetlana Sotnikova ${ }^{2}$ \\ ${ }^{1}$ Candidate of Sciences, associate professor, Department of Theory of Education, Kursk State \\ University, 305000, 33, Radischev str., Kursk, Russia \\ ${ }^{2}$ Candidate of Sciences, associate professor, Head of Department of Theory of Education, Kursk State \\ University, 305000, 33, Radischev str., Kursk, Russia
}

\begin{abstract}
Development of media literacy looks especially crucial in context of globalization characterized by a high level culture-language interaction. Contemporary education environment is defined by intensive information saturation which demands skills to act effectively and be flexible from a modern teacher in accordance with constantly changing needs of modern community. Evidently, media literacy is a significant component of professional competence for specialists of modern teacher training education. The advanced level of media literacy skills allows to raise efficacy and quality of teacher training education which is aimed at training a specialist who is ready for development, improvement and selfrealization in professional sphere. Media literacy is connected with applying information and communication technologies in theory and practice of contemporary professional education. So, the term "media literacy" implies future specialist's skills to work not only with mass media but with various information and communication sources allowing to search, select and present necessary information possibilities for solving academic, personal, cognitive and developing tasks.
\end{abstract}

\section{Introduction}

The analysis of modern teacher training education demonstrates rather insufficient level of media literacy skills of graduates. Future teachers turn out not to be ready to process information as there is no clear system of developing media awareness at universities [1, 2, 3].

The following contradiction can be traced in contemporary conditions:

- between the necessity of developing media literacy as an important component inherent in professional competence of a future teacher and absence of theoretical and technological aspects of developing this phenomenon in the current teacher training education system.

Educationists argue that using media literacy in class allows to involve additional data from various sources: reference literature, audio materials, newspapers, visual facilities, films, etc. $[4,5,6]$. 
So, it may be supposed that media application in class makes learning process more effective since the information acquired through various mass media channels constantly keeps up to date. In other words, students are provided with a huge amount of new data which requires analyzing, codifying and summarizing in order to be used as learning materials in future. New data acquisition which enriches students' knowledge in different subjects meets the demands of the contemporary education process and paradigm.

Media literacy is connected with developing new pedagogical technologies and examining teaching opportunities of mass media: TV, films, newspapers, radio, etc. This issue is discussed by L.M. Bazhenova (1992), E.A. Bondarenko (1994), I.S. Levshina (1998), Yu.N. Usov (1995), A.V. Khutorskoy (2001), C. Bazelgette (1992), D. Buckingham (1990), U. Carlsson and C. Von Feilitzen (1988), C. Metz (1996) and others $[7,8,9]$.

The term «media literacy» was introduced in Russian Pedagogics by A.V. Sharikov. According to him, the term "media literacy" is a calque from English «media education», where the first part is a contracted form of «mass media communication» [10, 11].

Educationists define the goal of media literacy in terms of its interpretation.

For instance, A.V. Sharikov considers the goal of media literacy to be media communicative competence, and it is to be interpreted as not the highest level of awareness in various spheres, but «a sufficient level of knowledge and skills for acquiring, understanding, creating and messaging with the help of means of communication» [10].

The analysis of special literature leads to a conclusion that the absence of universal understanding of the essence of media education concept causes differences in setting objectives. There are some points of view regarding the goal of media education which is specified by various approaches to interpreting the aims of this phenomenon in the world: it is media literacy, media culture, media competence, information culture, information literacy and critical thinking. Evidently, these goals are not identical [12, 13, 14].

Media literacy in this article is to be interpreted as a complex of systemized media awareness, media skills and value-based attitude to media literacy.

\section{Materials and methods}

Teacher's media literacy - a general, objective and new characteristic of a teacher's personality - is a complex social psychological concept which includes common elements (connection between a personality and environment) and individual (life experience, nature of behavior, mode of thinking and feelings).

The essence of teacher's media literacy is made up by the system of media awareness, media skills and value-based attitude to media education which reflects personal connection with environment (primarily, with students).

The process of developing media literacy skills implies using various kinds of activity: cognitive, academic and planning ones.

The active teaching methods: project method, role and business simulation games, disputes, discussions, brainstorming, «round tables»; practical (doing different tasks of practical character using media content). According to the level of cognitive activity we can classify: explaining-illustrative (the introduction of some data on media by a teacher, acquisition and processing of the data by the audience); reproductive (design and application of various exercises and tasks by the teacher using media content for students to master tools and techniques of their solving), problematic (topical analysis of situations / media text in order to develop critical thinking); partially-exploring or prompting or investigative (organization of exploring-creative activity) $[15,16]$. 


\section{Results}

Means of developing media literacy: exercises based on: topical situation communicative tasks, analysis of authentic audio-visual texts (broadcasts, films, video materials, interviews), illustrative staff (photos, drawings, pictures, etc.), analysis of texts of different genres, analysis of fiction and documentary films.

Skills necessary for media literacy are as follows: exposure to the peculiarities of different media language and ability to realize their influence regardless of the complexity of media texts; ability and readiness to make effort in order to acquire, understand the content of media texts; ability to distinguish emotional and well-reasoned reaction while acquiring information; development of competent supposition about the content of media texts; exposure to peculiarities of genres and ability to define their synthesis; understanding; ability to treat media texts critically regardless of their source significance $[17,18,19]$.

Table 1. Model of formation of media education skills of a future teacher of foreign languages.

\begin{tabular}{|c|}
\hline \\
\hline Approaches: student-oriented, problem-based, communicative, competence-based, socio-cultural \\
\hline $\begin{array}{l}\text { Principles: scientific character, connection of theory and practice, focus on the subject of the } \\
\text { learning process, interaction, information context, integration, module type, transparency, } \\
\text { individualization, professional orientation, novelty, problem-oriented, activity. }\end{array}$ \\
\hline $\begin{array}{l}\text { Active teaching methods: project-based, role play, disputes, discussion, brain storming, «round } \\
\text { tables»; practical (performing different types of practical tasks based on media material). According } \\
\text { to the level of cognitive activity: explaining-illustrative (delivering information on media, } \\
\text { processing and analyzing by the audience); reproductive (design and application of various } \\
\text { exercises and tasks using media to develop problem-solving skills), problematic (problem analysis } \\
\text { of situations or media texts to develop critical thinking skills); partly-searching or heuristic, } \\
\text { investigative (organizing searching-creative activities). }\end{array}$ \\
\hline $\begin{array}{l}\text { Means of developing media awareness: exercises based on problematic communicative situations, } \\
\text { exercises based on analysis of audio-visual texts (broadcasts, films, video materials, interviews), } \\
\text { exercises based on illustrative material (photos, pictures, etc.), exercises based on analysis of texts } \\
\text { of different genres, exercises based on analysis of fiction and documentary films. }\end{array}$ \\
\hline $\begin{array}{c}\text { Criteria: } \\
\text { 1)media knowledge (knowledge necessary for effective application of media means for solving } \\
\text { pedagogical issues in teaching foreign languages); } \\
\text { 2)media skills (skills to find, process, create, understand and transfer information introduced } \\
\text { through the system of media education means); } \\
\text { 3)valuable attitude to media education (need for self-improvement in media education). }\end{array}$ \\
\hline $\begin{array}{l}\text { Skills, necessary for personal media education: knowledge of language of various media and ability } \\
\text { to realize their influence regardless of media texts complexity; } \\
\text { ability to distinguish emotional and proved reaction for related acting; } \\
\text { developing a competent supposition about media text content; } \\
\text { awareness of genres' variety and ability to define their synthesis; } \\
\text { ability to evaluate media texts critically regardless of their sources. }\end{array}$ \\
\hline $\begin{array}{l}\text { Conditions of model realization: a) creating a special learning environment which demonstrates } \\
\text { educational opportunities of media means in solving typical academic issues; b) using a special } \\
\text { system of tasks which reflects techniques of applying media education means to solve cognitive and } \\
\text { educational issues; c) engaging students in project activity implying independent usage of media } \\
\text { education means; d) engaging students in permanent activity including search, selection and } \\
\text { presentation of significant data necessary for effective classes in the Internet and media sphere; e) } \\
\text { organizing students' interaction via data environment with all participants of a learning process. }\end{array}$ \\
\hline $\begin{array}{l}\text { Result: all-round developed personality of a future teacher of foreign languages capable of effective } \\
\text { applying means of media education to solve academic issues. }\end{array}$ \\
\hline
\end{tabular}




\section{Discussion}

The following means were used:

- exercises based on problem communicative tasks, exercises based on the analysis of authentic audio-visual texts (radio broadcasts, films, interviews);

- exercises based on illustrative background (photos, pictures, drawings, etc.);

- exercises based on the analysis of texts of different genres introduced in authentic press of the USA and Great Britain;

- exercises based on the analysis of authentic fiction and documentary films.

A set including the most typical tasks which are aimed at developing media literacy skills in context of teacher training education can look in the following way:

1. Prologue: Students' free definitions of the term "media literacy". Discussing and analyzing definitions of different scientists. What role do means of mass communication play in arranging learning process? When can media content be used in learning process?

2. Explication: Students are provided with brief theory on the topic.

Tasks for group work: make up a story in chain using the plan:

- Who is a media literate teacher of foreign languages?

- What knowledge and skills should he possess?

- What role do means of mass communication play in arranging learning process?

- How to integrate means of mass media communication in a foreign language class (or extracurricular activity, project work, etc.)?

3. Students should analyze information on one of topics from different sources (selection of messages is executed beforehand by students).

Tasks for individual work may be as follows:

- Look through the information and comment upon it.

- Which presentation of information do you find the best? Why?

- Does the information have any mistakes?

- Give recommendations for their correction.

- Make up a review for the provided message: give your arguments "for" and "against".

- Make up a plan with the help of which the provided information could be included in the class activities / extracurricular activities, etc.

Besides, students are to make up and analyze tasks for developing media awareness skills in context of arranging learning process with students. The ideas for the tasks and activities are designed by students themselves.

Special attention should be paid to the tasks of communicative type: express your attitude and comment on a video fragment and characterize its teaching potential in terms of goals of learning foreign languages, and using means of media literacy in solving academic and educative issues in education and reflection.

The suggested ideas can be performed in case of following the system of requirements:

a) exposure of future teachers to a special educational environment which demonstrates educational opportunities of media means while solving typical academic problems;

b) usage of a special task system denoting method of applying means of media literacy for solving academic, cognitive and educative goals in learning foreign languages;

c) engagement of students in project activity which implies independent students' application of media literacy means;

e) engagement of students in constant work of searching, selecting and presenting significant data necessary for successful classes in the Internet and media sphere;

f) organization of interaction of future teachers through information environment with all participants of the education process $[20,21]$. 
According to the above stated criteria the rubric for assessing media literacy skills of future teachers of foreign languages was designed.

Table 2. Rubric for assessing media literacy skills of future teachers of foreign languages.

\begin{tabular}{|c|c|c|c|}
\hline \multirow{2}{*}{$\begin{array}{l}\text { Levels I } \\
\text { Criteria }\end{array}$} & \multicolumn{3}{|c|}{ Characteristics } \\
\hline & high & medium & low \\
\hline 1 & 2 & 3 & 4 \\
\hline \multirow[t]{5}{*}{ Knowledge } & $\begin{array}{l}\text { Is aware of the necessity to } \\
\text { apply mass media in } \\
\text { organization of a teaching- } \\
\text { learning process }\end{array}$ & $\begin{array}{c}\text { Realizes the necessity to } \\
\text { apply mass media in } \\
\text { organization of a teaching- } \\
\text { learning process }\end{array}$ & $\begin{array}{c}\text { Knows about the opportunity of } \\
\text { applying mass media in } \\
\text { organization of a teaching- } \\
\text { learning process }\end{array}$ \\
\hline & $\begin{array}{l}\text { Is aware of principles, } \\
\text { methods and forms of mass } \\
\text { communication }\end{array}$ & $\begin{array}{l}\text { Possesses a notion about } \\
\text { principles, methods and } \\
\text { forms of mass } \\
\text { communication }\end{array}$ & $\begin{array}{l}\text { Possesses a general idea about } \\
\text { principles, methods and forms } \\
\text { of mass communication }\end{array}$ \\
\hline & $\begin{array}{c}\text { Is aware of basic principles } \\
\text { of perceiving and } \\
\text { understanding media } \\
\text { messages }\end{array}$ & $\begin{array}{c}\text { Possesses a notion about } \\
\text { basic principles of perceiving } \\
\text { and understanding media } \\
\text { messages }\end{array}$ & $\begin{array}{c}\text { Possesses a general idea about } \\
\text { basic principles of perceiving } \\
\text { and understanding media } \\
\text { messages }\end{array}$ \\
\hline & $\begin{array}{c}\text { Realizes mass media } \\
\text { influence on education } \\
\text { process, formation and } \\
\text { development of a personality }\end{array}$ & \begin{tabular}{|} 
Realizes weakly mass media \\
influence on education \\
process, formation and \\
development of a personality
\end{tabular} & $\begin{array}{l}\text { Possesses a notion about mass } \\
\text { media influence on education } \\
\text { process, formation and } \\
\text { development of a personality }\end{array}$ \\
\hline & $\begin{array}{l}\text { Realizes consequences of } \\
\text { mass media influence on } \\
\text { psyche }\end{array}$ & $\begin{array}{c}\text { Realizes weakly } \\
\text { consequences of mass media } \\
\text { influence on psyche }\end{array}$ & $\begin{array}{c}\text { Possesses a notion about } \\
\text { consequences of mass media } \\
\text { influence on psyche }\end{array}$ \\
\hline \multirow[t]{4}{*}{ Skills } & $\begin{array}{l}\text { Is able to get, create, find, } \\
\text { understand keep and deliver } \\
\text { different information } \\
\text { independently }\end{array}$ & $\begin{array}{l}\text { Is able to get, create, find, } \\
\text { understand keep and deliver } \\
\text { different information with } \\
\text { someone's partial assistance }\end{array}$ & $\begin{array}{l}\text { Is able to get, create, find, } \\
\text { understand keep and deliver } \\
\text { different information with } \\
\text { someone's assistance }\end{array}$ \\
\hline & $\begin{array}{l}\text { Is able to communicate } \\
\text { using non-verbal forms of } \\
\text { communication with the } \\
\text { help of technical tools }\end{array}$ & $\begin{array}{c}\text { Is able to communicate using } \\
\text { non-verbal forms of } \\
\text { communication with the help } \\
\text { of technical tools with } \\
\text { someone's partial assistance }\end{array}$ & $\begin{array}{l}\text { Is able to communicate using } \\
\text { non-verbal forms of } \\
\text { communication with the help of } \\
\text { technical tools with someone's } \\
\text { assistance }\end{array}$ \\
\hline & $\begin{array}{c}\text { Develops and proves } \\
\text { independently alternative } \\
\text { views on information }\end{array}$ & $\begin{array}{c}\text { Develops and proves } \\
\text { alternative views on } \\
\text { information with someone's } \\
\text { partial assistance }\end{array}$ & $\begin{array}{l}\text { Develops and proves } \\
\text { alternative views on information } \\
\text { only with someone's assistance }\end{array}$ \\
\hline & $\begin{array}{l}\text { Is able to organize learning } \\
\text { process on the basis of } \\
\text { media communication } \\
\text { means }\end{array}$ & $\begin{array}{l}\text { Is able to organize learning } \\
\text { process on the basis of media } \\
\text { communication means with } \\
\text { someone's partial assistance } \\
\end{array}$ & $\begin{array}{c}\text { Is able to organize learning } \\
\text { process on the basis of media } \\
\text { communication means only with } \\
\text { someone's assistance }\end{array}$ \\
\hline \multirow[t]{3}{*}{$\begin{array}{l}\text { Valuable } \\
\text { attitude to } \\
\text { media } \\
\text { education }\end{array}$} & $\begin{array}{c}\text { Realizes the necessity to } \\
\text { form media literacy skills } \\
\text { as significant characteristic } \\
\text { of a personality of a future } \\
\text { teacher } \\
\end{array}$ & $\begin{array}{c}\text { Realizes weakly the necessity } \\
\text { to form media literacy skills } \\
\text { as significant characteristic of } \\
\text { a personality of a future } \\
\text { teacher }\end{array}$ & $\begin{array}{l}\text { Knows about the necessity to } \\
\text { form media literacy skills as } \\
\text { significant characteristic of a } \\
\text { personality of a future teacher }\end{array}$ \\
\hline & $\begin{array}{c}\text { Realizes mismatch of own } \\
\text { level of media literacy skills } \\
\text { and set norms and } \\
\text { requirements }\end{array}$ & $\begin{array}{l}\text { Realizes mismatch of own } \\
\text { level of media literacy skills } \\
\text { and set norms and } \\
\text { requirements in definite } \\
\text { academic situations }\end{array}$ & $\begin{array}{c}\text { Doesn't Realizes mismatch of } \\
\text { own level of media literacy } \\
\text { skills and set norms and } \\
\text { requirements }\end{array}$ \\
\hline & $\begin{array}{l}\text { Possesses a necessity for } \\
\text { self-improvement in media } \\
\text { education }\end{array}$ & $\begin{array}{c}\text { Possesses an interest for self- } \\
\text { improvement in media } \\
\text { education }\end{array}$ & $\begin{array}{l}\text { Possesses a wish for self- } \\
\text { improvement in media } \\
\text { education }\end{array}$ \\
\hline
\end{tabular}




\section{Conclusion}

The outcome of this model is an all-round developed personality of a future teacher who is to succeed in applying means of media literacy effectively in order to solve educational tasks, in particular: academic, developing, cognitive and educative ones.

Obviously, modern multimedia technologies can be referred to as the crucial means of creating and developing professional background, competencies, outlook of a specialist in any field of professional activity.

\section{References}

1. S.V. Akmanova, L.V. Kurzaeva, N.A. Kopylova,. Med. Edu., 2: 37-49 (2018)

2. B. Andresen, K. Brink, Multimedia in Education: Curriculum. UNESCO Institute for Information Technologies in Education, 141 (2013)

3. E. Bal, Proc. Comp. Sci. 120, 177-181 (2017)

4. I.V. Chelysheva, Med. Edu., 1, 71-77 (2016).

5. D. Akgunduz, O. Akinoglu, The Turk. OJ of Ed. Techn. 2, 106-115 (2016)

6. A. Anders, Comp. \& Edu., 127: 13-29 (2018). https://doi.org/10.1016/j.compedu.2018.08.009.

7. V.S. Toiskin, V.V. Krasilnikov, Media education in information-educational environment, 122. (2009).

8. A. Price, et al. First year nursing students use of social media within education: Results of a survey. Nurse Education Today, 61: 70-76. [Electronic resource]. (2018). URL: https://doi.org/10.1016/jmedt.2017.10.013

9. I. Hazanov, Med. Edu., 1 (2018)

10. A.V. Sharikov, S.N. Fazulianova, E.V. Petrushkina, Harmonizing media and society (media resources and media literacy in Samara schools), 50 (2016)

11. A.V. Fedorov, Dictionary of terms on media education, media pedagogics, media literacy, media competence, 6, (2014)

12. L. Rueda, J. Benitez, J. Braojos, Info. \& Manag., 54-8: 1059-1071 (2017).

13. A. Tess, Comp. in Hum. Beh., 29, 5, A60-A68 (2013) https://doi.org/10.1016/j.chb.2012.12.032

14. A. Kaplan, M. Haenlein, Bus. Hor., 59, 4, 441-450 (2016) https://doi.org/10.1016/j.bushor.2016.03.008

15. N. Dabbagh, A. Kitsantas, Personal Learning Environments, social media, and selfregulated learning: A natural formula for connecting formal and informal learning. The Internet and Higher Education. Vol. 15, Issue 1, pp. 3-8. (2012). https://doi.org/10.1016/j.iheduc.2011.06.002

16. O. Florescu, Proc. Soc. and Behav. Sc., 149, 349-353 (2014)

17. E. Frolova, T. Ryabova, O. Rogach. Med. Edu., 2 (2018)

18. S. Wan, Z. Niu, An e-learning recommendation approach based on the selforganization of learning resource. Knowledge-Based Systems, 160: 71-81. (2018).

19. I. Zhilavskaya, Uchitel. gaz. Mos., 2, (2018) http://www.ug.ru/article/1036/Accessed 20 February 2020.

20. E.A. Bondarenko, Med. Awar. in Rus. URL: http://vio.uchim.info/Vio_119/cd_site/articles/art_2_7.htm/ (2013) 
21. E. Pukhomelina, E. Uchit. G.. Mos. 4, (2016) http://www.ug.ru/archive/67446 / Accessed 3 March 2020. 